\title{
Evaluation of Six Plant Essential Oils against Three Stored Product Insects and Their Effects on the Haemogram under Laboratory Conditions
}

\author{
M.E. Tawfeek, Amany M.H. Abu-Shall, Abir A.Gad, M. Mohey \\ Department of Applied Entomology and Zoology, Faculty of Agriculture, Alexandria University, Egypt
}

\begin{abstract}
The effect of six plant essential oils against three stored grain insects, Sitophilus oryzae, Rhizopertha dominica and Tribolium castaneum were studied under laboratory conditions. The tested oils are namely, fennel oil (Foeniculum vulgare), caraway oil (Carum carvi), cinnamon oil (Cinnamomum verum), citronella oil (Cymbopogon winterianus), nutmeg oil (Myristica fragrans) and black cumin oil (Nigella sativa). The result showed that increasing of the oil concentration and exposure times significantly increased the mortality percentage.

Generally, the toxicity of essential oils at all tested concentrations increased with the increasing of exposure time. So, the results indicated that toxicity of all tested essential oil against the three stored grain insects at the high concentration was recorded high mortality faster than low concentration.

The tested essential oils significantly decreased the different haemocyte counts in tested insects, cinnamon oil markedly increased the haemocyte surface areas in the tested insects especially the surface area of oenocytoides in $T$. castaneum.

The recorded results indicate that the essential oils of fennel, caraway, cinnamon and citronella could be applicable to the management of $S$. oryzae, $R$. dominica and T. castaneum adults.
\end{abstract}

Key words: Sitophilus oryzae, Rhizopertha dominica, Tribolium castaneum, plant essential oils, haemocytes.

\section{INTRODUCTION}

Stored product insects have been considered serious pests over the world. They cause great losses in weight and quality of the stored products (Pugazhvendan et al., 2009). Losses of grain in storage due to insects are main components of the insect damage in agricultural production like several crops, wheat, rice, pasta, beans, nuts and many other crops. The stored products are liable to be attacked by many coleopteran insect pests; e.g. red flour beetle (Tribolium castaneum), rice weevil beetle (Sitophilus oryzae) and lesser grain borer (Rhizopertha dominica).

Control of stored product insects depend strongly on the use of synthetic insecticides and fumigants, which has led to problems such as environmental disturbances, increasing costs of application, pest resurgence, pest resistance to pesticides and lethal effects on non-target organisms, in addition to direct toxicity to users (Isman 2006). Biological control, such as green pesticides, may be an effective way for storedproduct pest management. Green or botanical pesticides have the advantage of providing novel modes of action against insects that can reduce the risk of cross-resistance as well as offering new leads for design of target-specific molecules (Isman, 2008).

Plant essential oils in general have been recognized as an important natural resource of insecticides (Gbolade et al., 2000), which are often responsible for a plant distinctive scent or taste.
Essential oils extracted from more than 75 plant species have been evaluated for fumigant toxicity against stored product insects. Fumigant toxicity tests conducted with essential oils of plants (mainly belonging to Apiaceae, Lamiaceae, Lauraceae and Myrtaceae), which have strongly effect on stored product insects such as T.castaneum, $R$. dominica, $S$. oryzae and $S$. zeamais (Rajendran and Srianjini, 2008). There are 17.500 aromatic species that occur in higher plants (Bruneton, 1999). The plant essential oils major constituents, monoterpenes, are also of interest because of their toxicity to insects and other potent biological activities (Kubo et al., 1994; Basilico and Basilico, 1999). Plant essential oils and their components have been shown to possess potential for development as new fumigants and they may have advantages over conventional fumigants in terms of low mammalian toxicity, rapid degradation and local availability (Isman, 2008).

The present study aims to evaluate the efficacy of six plant essential oils against three stored insects $S$. oryzae, $R$. dominica and $T$. castaneum, and their effects on haemolymph cells.

\section{MATERIALS AND METHODS 1- Insect culture \\ Adults of rice weevil (Sitophilus oryzae), lesser grain borer (Rhizopertha dominica) and red flour beetle (Tribolium castaneum), were collected from infested grains and flour from local market, and}


separately rearing under laboratory conditions of 30 $\pm 2{ }^{\circ} \mathrm{C}$ and $70-75 \%$ R.H.

\section{1- Culture of Sitophilus oryzae and Rhizopertha dominica.}

The adults of $S$. oryzae and $R$. dominica collected from infested grains were brought to the laboratory and kept in plastic jar $(32 \times 50 \mathrm{~cm})$. Wheat was sterilized by heating at $70{ }^{\circ} \mathrm{C}$ for $1 \mathrm{hr}$., then cooled and allowed to reabsorb before use. After that, it was transferred to separate jar until depth of $10 \mathrm{~cm}$. Adults (200 - 400 insects) were collected from the infested grains and added into each jar, which contain sterilized culture of wheat. All jars were painted by aband of Vaseline around the inside edge of the jar to prevent the escaping of insects, and sealed with muslin. The jars were placed at room temperature about $\left(30 \pm 2{ }^{\circ} \mathrm{C}\right)$ and relative humidity of $70-75 \%$. After two weeks; insects were sieved out and transferred to another jar. Then, adults were used for experimental work, according to El-Disouky (2002).

\section{2- Culture of Tribolium castaneum.}

The adult of $T$. Castaneum collected from infested wheat flour was brought to the laboratory and placed in plastic jar $(32 \times 50 \mathrm{~cm}) . T$. Castaneum kept in a media consists of four parts of wheat flour and one part of brewer's yeast. The whole wheat flour has been sieved to remove all of the large particles in the flour. This culture will be maintained at the same previous conditions.

\section{2- Source of essential oils}

Six of the tested plant essential oils, e.g. fennel oil (Foeniculum vulgare), caraway (Carum carvi), cinnamon (Cinnamomum verum), citronella (Cymbopogon winterianus), nutmeg (Myristica fragrans) and black cumin (Nigella sativa) were provided by Faculty of pharmacy, Alexandria University (Table 1).

\section{3- Bioassay tests}

3.1- Evoluation of plant essential oils against three stored insects.

The efficacy of six plant (Table 1) essential oils was evaluated against the adults of $S$. oryzae, $R$. dominica and T. Castaneum at different concentrations. All concentrations of tested essential oils were diluted in acetone. The contact toxicity of essential oils was tested by using residual film technique and appllied directly on petri dish $(9 \mathrm{~cm})$ without any grains according to Qi and Burkholder (1981). One ml. of each concentration was pipetted in Petri-dish. After evaporation of acetone, 20 adults were placed in each Petri-dish. Four replicates were carried out of each concentration and control. Mortality percentage was recoded after 1, 2, 3, 4, 5, $6,7,8,9$ and 10 days. The percentage of mortality was corrected for control mortality using Abbott's formula (Abbott, 1925). Toxicity factor was calculated as following:-

Toxicity factor $=\mathrm{LC}_{50}$ of the compound $/ \mathrm{LC}_{50}$ of more toxic compound

\section{2- Effects of the essential oils on the haemocytes} of the tested insects.

The haemocytes of adults were examined by light microscope. Differential haemocytes count (DHC) was determined in citronella oil at concentrations of $0.0037,0.0322$ and $0.052 \mathrm{mg} / \mathrm{cm}^{2}$ for $S$. oryzae, $R$. dominica and $T$. castaneum, respectively. Also, cinnamon oil at concentrations of $0.0063,0.0072$ and $0.0064 \mathrm{mg} / \mathrm{cm}^{2}$ for $S$. oryzae, $R$. dominica and $T$. castaneum, respectively. While, caraway oil examined at concentrations of 0.008 , 0.028 and $0.041 \mathrm{mg} / \mathrm{cm}^{2}$ on $S$. oryzae, $R$. dominica and $T$. castaneum, respectively. Fennel oil at concentrations of $0.0098,0.012$ and $0.019 \mathrm{mg} / \mathrm{cm}^{2}$ on $S$. oryzae, $R$. dominica and $T$. castaneum, respectively. Furthermore, nutmeg oil examined at concentrations of 0.027 and $0.041 \mathrm{mg} / \mathrm{cm}^{2}$, finally black cumin at concentrations of 0.028 and 0.032 $\mathrm{mg} / \mathrm{cm}^{2}$ on $S$. oryzae and $R$. dominica, respectively.

Blood samples obtained from 5 adults of each treated insects with tested oils and control was prepared for (DHC) (Gad, 2006). Each blood sample was replicated five times. The appropriate number of each tested oil and control were separately smeared to thin film between two glass slides.

Table 1: Plant essential oils; common name, scientific name; family, and series of concentrations used in the study.

\begin{tabular}{|c|c|c|}
\hline Common name & Scientific name \& Family & Concentrations used $\left(\mathrm{mg} / \mathrm{cm}^{2}\right)$ \\
\hline Fennel & Foeniculum vulgare (Apiaceae) & $\begin{array}{l}0.004,0.008,0.01,0.02,0.03,0.04,0.05 \text { and } \\
0.06\end{array}$ \\
\hline Caraway & Carum carvi (Umbelliferae) & $\begin{array}{l}0.004,0.008,0.01,0.03,0.05,0.06,0.08,0.09 \\
\text { and } 0.11\end{array}$ \\
\hline Cinnamon & Cinnamomum verum (Lauraceae) & $0.004,0.008,0.01,0.02,0.03$ and 0.04 \\
\hline Citronella & Cymbopogon winterianus (Poaceae) & $\begin{array}{l}0.004,0.006,0.008,0.01,0.02,0.03,0.05 \text {, } \\
0.08,0.09,0.11 \text { and } 0.13\end{array}$ \\
\hline Nutmeg & Myristica fragrans (Myristicaceae) & $\begin{array}{l}0.008,0.01,0.03,0.05,0.06,0.08,0.09,0.11 \\
\text { and } 0.13\end{array}$ \\
\hline Black cumin & Nigella sativa (Ranunculaceae) & $\begin{array}{l}0.004,0.006,0.008,0.01,0.03,0.05,0.06 \text { and } \\
0.08\end{array}$ \\
\hline
\end{tabular}


The smeared blood were air dried, stained with Wright's blood stain (Martha and Hachiro, 1971) for 1 minute and distained for $2 \mathrm{~min}$. with $70 \%$ ethyl alcohol.

The blood cell types were examined and identified under oil immersion (100x) using a light microscope. DHC were carried out in random scan of blood films (approximately 100 haemocytes for each film). The identification of haemocytes types were performed according to Arnold (1974). Haemocyte surface areas were measured by micrometric slide.

\section{4- Statistical analysis}

All the tested criteria were statistically analyzed compared using (F) test and Least Significant Differences (L. S. D) at 0.01 probability level, (Steel and Torrie, 1980).

\section{RESULTS AND DISCUSSION}

\section{1- Effect of six essential oils against three stored grain insects.}

\section{1- Sitophilus oryzae}

Mortality percentages of six essential oils on the $S$. oryzae adults were evaluated at different concentrations after different exposure times by using a residual film method. The median lethal concentration $\left(\mathrm{LC}_{50}\right.$ values) and the slope values were calculated.

Results showed that the fennel oil at concentration of $0.01 \mathrm{mg} / \mathrm{cm}^{2}$ was achieved $100 \%$ mortality after 10 days of exposure. The same effect with the caraway oil and nutmeg oil at low concentrations of 0.008 and $0.01 \mathrm{mg} / \mathrm{cm}^{2}$. While, the concentration of $0.008 \mathrm{mg} / \mathrm{cm}^{2}$ of citronella oil and black cumin oil gave the same percentage after 8 days of exposure.

On the other hand, the toxic effects with the high concentrations of fennel oil 0.05 and 0.06 $\mathrm{mg} / \mathrm{cm}^{2}$ were achieved $100 \%$ mortality after 5 days of exposure. Also, the same trend with the caraway oil at concentrations of $0.05,0.06,0.08,0.09$ and $0.1 \mathrm{mg} / \mathrm{cm}^{2}$. Citronella oil at concentration of 0.08 $\mathrm{mg} / \mathrm{cm}^{2}$ gave the same percentage after the $2^{\text {nd }}$ day. Approximately, cinnamon oil was achieved the best toxicity against the $S$. oryzae. It was caused $100 \%$ mortality at concentration of $0.01 \mathrm{mg} / \mathrm{cm}^{2}$ after 8 days of exposure compering with the other tested essential oils.

Generally, the toxicity of essential oils at all tested concentrations increased with the increasing of exposure time. Hence, the results indicate that toxicity of essential oil against $S$. oryzae at the high concentration was recorded $100 \%$ mortality faster than low concentration.

The mentioned results showed that the toxicity of all tested oils against $S$. oryzae was depended on oil concentration and time of exposure. According to the $\mathrm{LC}_{50}$ values after 6 days of exposure (Table 2 ), cinnamon oil was more toxic than caraway oil by about 8.75 times. The desending order of toxicity as following: cinnamon, black cumin, citronella, nutmeg, fennel and caraway oil, with the $\mathrm{LC}_{50}$ values $0.0012,0.0047,0.0050,0.0053,0.0059$ and $0.0105 \mathrm{mg} / \mathrm{cm}^{2}$, respectively.

\section{2 - Rhizopertha dominica}

The tested essential oils caused more mortality in high concentrations and the toxicity was increased with the increasing of exposure time. Fennel oil at concentrations of 0.06 and 0.05 $\mathrm{mg} / \mathrm{cm}^{2}$ achieved $97.5 \%$ and $95 \%$ mortality after 1 day of exposure, respectively. While, Fennel oil at concentration of $0.04 \mathrm{mg} / \mathrm{cm}^{2}$ caused $93.8 \%$ mortality after 6 days of exposure. In respect of the caraway oil, the results revealed that the toxicity at the high concentration of $0.11 \mathrm{mg} / \mathrm{cm}^{2}$ was recorded a high mortality $90 \%$ and $98.8 \%$ after 2 and 10 days of exposure, respectively. Only, citronella oil at the same concentration achieved $100 \%$ mortality after 7 days of exposure. While, cinnamon oil was gave the same mortality percentage at concentrations of 0.03 and $0.04 \mathrm{mg} / \mathrm{cm}^{2}$ after 9 days exposure.

On the other hand, the toxicity of caraway oil and black cumin oil at the low concentration of 0.03 $\mathrm{mg} / \mathrm{cm}^{2}$ achieved $90 \%$ mortality after 10 days of exposure, respectively. But, nutmeg oil was gave the same percentage at concentrations of 0.09 and 0.13 $\mathrm{mg} / \mathrm{cm}^{2}$ after 10 and 6 days of exposure, respectively. While, black cumin oil at concentration of $0.08 \mathrm{mg} / \mathrm{cm}^{2}$ achieved $98.8 \%$ mortality after 10 days exposure and $95 \%$ after 6 days of exposure.

Table 2: Relative toxicity of six essential oils against $S$. oryzae after 6 days of exposure.

\begin{tabular}{lccccc}
\hline \multirow{2}{*}{ Essential oils } & $\begin{array}{c}\mathbf{L C}_{\mathbf{5 0}} \\
\left(\mathbf{m g} / \mathbf{c m}^{\mathbf{2}}\right)\end{array}$ & \multicolumn{2}{c}{ Confidence limits } & \multirow{2}{*}{ Slope $\pm \mathbf{S E}$} & \multirow{2}{*}{ Toxicity factor } \\
\cline { 3 - 5 } & 0.0012 & 0.0001 & 0.0026 & $0.96 \pm 0.24$ & 1.00 \\
\hline Cinnamon & 0.0047 & 0.0037 & 0.0053 & $2.90 \pm 0.5$ & 3.92 \\
\hline Black cumin & 0.0050 & 0.0042 & 0.0056 & $3.10 \pm 0.5$ & 4.17 \\
\hline Citronella & 0.0053 & 0.0018 & 0.0086 & $1.05 \pm 0.2$ & 4.42 \\
\hline Nutmeg & 0.0059 & 0.0047 & 0.0070 & $2.08 \pm 0.3$ & 4.92 \\
\hline Fennel & 0.0105 & 0.0087 & 0.0135 & $1.80 \pm 0.3$ & 8.75 \\
\hline Caraway & & &
\end{tabular}


Relative toxicity of six essential oils against R.dominica shown according to the $\mathrm{LC}_{50}$ values after 6 days of exposure, cinnamon oil was the most toxic oil. The desending order of toxicity as following: cinnamon, fennel, caraway, citronella, black cumin and nutmeg oil, with the $\mathrm{LC}_{50}$ values $0.0074,0.014,0.029,0.029,0.035$ and 0.063 $\mathrm{mg} / \mathrm{cm}^{2}$, respectively (Table 3 ). At the same trend in $S$. oryzae, the toxicity of all tested oils against R.dominica was depended on concentration and time of exposure.

\section{3- Tribolium castaneum}

The essential oils were evaluated against the adult of $T$. castaneum by using the residual film method. T. castaneum has shown tolerance to the nutmeg oil and the black cumin oil until 1000 $\mathrm{mg} / \mathrm{cm}^{2}$. The mortality percentage was recorded after $1,2,3,4,5,6,7,8,9$, and 10 days. Also, the median lethal concentration $\left(\mathrm{LC}_{50}\right)$ and the slope values were calculated.

The effect of fennel oil against $T$. castaneum showed high mortality with high concentration and after exposure times. Fennel oil at concentrations of 0.06 and $0.05 \mathrm{mg} / \mathrm{cm}^{2}$ achieved $80 \%$ and $78.8 \%$ mortality, respectively, after 10 days of exposure. The same trend, were observed with caraway oil, which gave the same mortality percentage $(80 \%)$ at the high concentration of $0.11 \mathrm{mg} / \mathrm{cm}^{2}$ after 8 days of exposure. While, citronella oil at the same concentration $\left(0.11 \mathrm{mg} / \mathrm{cm}^{2}\right)$ achieved $95 \%$ mortality after 9 days of exposure. On the other hand, cinnamon oil was recorded $91.3 \%$ mortality at concentrations of 0.04 and $0.03 \mathrm{mg} / \mathrm{cm}^{2}$ after 1 day and 10 days of exposure, respectively.

Results in (Table 4) showed relative toxicity of four tested essential oils against $T$. castaneum. Based on the $\mathrm{LC}_{50}$ values after 6 days of exposure, cinnamon oil was more toxic than fennel oil by about 2.74 times, 3.58 than citronella and 6.06 times than caraway oil, with the $\mathrm{LC}_{50}$ values 0.0125 , $0.0343,0.0447$ and $0.0758 \mathrm{mg} / \mathrm{cm}^{2}$, respectively.

In concoulison, citronella oil was more toxic against $S$. oryzae than $R$. dominica and $T$. castaneum by about 5.8 and 8.8 times, respectively (Table 5). While, the treatment with cinnamon oil against $S$. oryzae was more toxic than $R$. dominica and $T$. castaneum by about 6.2 and 10.4 times, respectively (Table 6). On the other hand, the caraway oil was more toxic against $S$. oryzae than $R$. dominica and $T$. castaneum by about 2.8 and 7.2 times, repectively (Table 7). While, the effect of fennel oil was more toxic against $S$. oryzae than $R$. dominica and $T$. castaneum by about 2.4 and 5.8 times, respectively (Table 8). Only, the nutmeg oil and black cumin oil affected on $S$. oryzae and $R$. dominica. The treatment with nutmeg oil and black cumin oil against $S$. oryzae were more toxic than $R$. dominica by about 11.9 and 7.5 times, respectively (Tables 9 and 10).

Table 3: Relative toxicity of six essential oils against $R$. dominica after 6 days of exposure.

\begin{tabular}{lccccc}
\hline \multirow{2}{*}{ Essential oils } & $\mathbf{L C}_{\mathbf{5 0}}$ & \multicolumn{2}{c}{ Confidence limits } & \multirow{2}{*}{ Slope $\pm \mathbf{S E}$} & \multirow{2}{*}{ Toxicity factor } \\
\cline { 3 - 5 } & $\left(\mathbf{m g} / \mathbf{c m}^{\mathbf{2}}\right)$ & Lower & Upper & & \\
\hline Cinnamon & 0.0074 & 0.0057 & 0.009 & $1.60 \pm 0.23$ & 1.00 \\
\hline Fennel & 0.014 & 0.010 & 0.017 & $3.00 \pm 0.70$ & 1.89 \\
\hline Caraway & 0.029 & 0.020 & 0.035 & $2.20 \pm 0.37$ & 3.92 \\
\hline Citronella & 0.029 & 0.021 & 0.041 & $0.72 \pm 0.17$ & 3.92 \\
\hline Black cumin & 0.035 & 0.028 & 0.044 & $1.30 \pm 0.20$ & 4.73 \\
\hline Nutmeg & 0.063 & 0.057 & 0.069 & $3.50 \pm 0.47$ & 8.51 \\
\hline
\end{tabular}

Table 4: Relative toxicity of four essential oils against $T$. castaneum after 6 days of exposure.

\begin{tabular}{lccccc}
\hline \multirow{2}{*}{ Essential oils } & $\begin{array}{c}\mathbf{L C}_{\mathbf{5 0}} \\
\left(\mathbf{m g} / \mathbf{c m}^{\mathbf{2}}\right)\end{array}$ & \multicolumn{2}{c}{ Confidence limits } & \multirow{2}{*}{ Slope $\pm \mathbf{S E}$} & \multirow{2}{*}{ Toxicity factor } \\
\cline { 3 - 4 } Cinnamon & 0.0125 & 0.011 & $\mathbf{U p p e r}$ & & \\
\hline Fennel & 0.0343 & 0.031 & 0.037 & $2.5 \pm 0.21$ & 1.00 \\
\hline Citronella & 0.0447 & 0.038 & 0.051 & $1.9 \pm 0.22$ & 3.58 \\
\hline Caraway & 0.0758 & 0.070 & 0.081 & $3.7 \pm 0.34$ & 6.06 \\
\hline
\end{tabular}

Table 5: Relative toxicity of citronella oil against three stored insects after 6 days of exposure.

\begin{tabular}{lcccc}
\hline \multirow{2}{*}{ Insects } & \multirow{2}{*}{$\mathbf{L C}_{\mathbf{5 0}}\left(\mathbf{m g} / \mathbf{c m}^{2}\right)$} & \multicolumn{2}{c}{ Confidence limits } & \multirow{2}{*}{ Toxicity factor } \\
\cline { 3 - 4 } & & Lower & Upper & \\
\hline S. oryzae & 0.005 & 0.004 & 0.005 & 1.0 \\
\hline R. dominica & 0.029 & 0.021 & 0.041 & 5.8 \\
\hline T. castaneum & 0.044 & 0.007 & 0.022 & 8.8 \\
\hline
\end{tabular}


Table 6: Relative toxicity of cinnamon oil against three stored insects after 6 days of exposure.

\begin{tabular}{lcccc}
\hline \multirow{2}{*}{ Insects } & \multirow{2}{*}{$\mathbf{L C}_{\mathbf{5 0}}\left(\mathbf{m g} / \mathbf{c m}^{\mathbf{2}}\right)$} & \multicolumn{2}{c}{ Confidence limits } & \multirow{2}{*}{ Toxicity factor } \\
\cline { 3 - 5 } & 0.0012 & Lower & Upper & \\
\hline S. oryzae & 0.0074 & 0.0001 & 0.0026 & 1.0 \\
\hline R. dominica & 0.0125 & 0.0057 & 0.009 & 6.2 \\
\hline T. castaneum & 0.011 & 0.014 & 10.4 \\
\hline
\end{tabular}

Table 7: Relative toxicity of caraway oil against three stored insects after 6 days of exposure.

\begin{tabular}{lcccc}
\hline \multirow{2}{*}{ Insects } & \multirow{2}{*}{$\mathbf{C C}_{\mathbf{5 0}}\left(\mathbf{m g} / \mathbf{c m}^{\mathbf{2}}\right)$} & \multicolumn{2}{c}{ Confidence limits } & \multirow{2}{*}{ Toxicity factor } \\
\cline { 2 - 4 } & & Lower & Upper & \\
\hline S. oryzae & 0.0105 & 0.0087 & 0.013 & 1.0 \\
\hline R. dominica & 0.029 & 0.020 & 0.035 & 2.8 \\
\hline T. castaneum & 0.0758 & 0.070 & 0.081 & 7.2 \\
\hline
\end{tabular}

Table 8: Relative toxicity of fennel oil against three stored insects after 6 days of exposure.

\begin{tabular}{lcccc}
\hline \multirow{2}{*}{ Insects } & \multirow{2}{*}{$\mathbf{L C}_{\mathbf{5 0}}\left(\mathbf{m g} / \mathbf{c m}^{\mathbf{2}}\right)$} & \multicolumn{2}{c}{ Confidence limits } & \multirow{2}{*}{ Toxicity factor } \\
\cline { 3 - 5 } & & Lower & Upper & \\
\hline S. oryzae & 0.0059 & 0.0047 & 0.0070 & $\mathbf{1 . 0}$ \\
\hline R. dominica & 0.014 & 0.010 & 0.017 & $\mathbf{2 . 4}$ \\
\hline T. castaneum & 0.0343 & 0.031 & 0.037 & $\mathbf{5 . 8}$ \\
\hline
\end{tabular}

Table 9: Relative toxicity of nutmeg oil against $S$. oryzae and $R$. dominica after 6 days of exposure.

\begin{tabular}{lcccc}
\hline \multirow{2}{*}{ Insects } & \multirow{2}{*}{$\mathbf{L C}_{\mathbf{5 0}}\left(\mathbf{m g} / \mathbf{c m}^{\mathbf{2}}\right)$} & \multicolumn{2}{c}{ Confidence limits } & \multirow{2}{*}{ Toxicity factor } \\
\cline { 3 - 4 } & 0.0053 & Lower & Upper & \\
\hline S.oryzae & 0.063 & 0.0018 & 0.0086 & 1.0 \\
\hline R. dominica & 0.057 & 0.069 & 11.9 \\
\hline
\end{tabular}

Table 10: Relative toxicity of black cumin oil against $S$. oryzae and $R$. dominica after 6 days of exposure.

\begin{tabular}{lcccc}
\hline \multirow{2}{*}{ Insects } & \multirow{2}{*}{$\mathbf{L C}_{\mathbf{5 0}}\left(\mathbf{m g} / \mathbf{c m}^{\mathbf{2}}\right)$} & \multicolumn{2}{c}{ Confidence limits } & \multirow{2}{*}{ Toxicity factor } \\
\cline { 2 - 4 } & 0.0047 & Lower & Upper & \\
\hline S. oryzae & 0.035 & 0.0037 & 0.0053 & 1.0 \\
\hline R. dominica & 0.028 & 0.044 & 7.5 \\
\hline
\end{tabular}

In the present study, the contact toxicity of six essential oils (fennel, carway, cinnamon, citronella, black cumin and nutmeg) using a residual film method were evaluated against the main three stored-products pests, $S$. oryzae, $R$. dominica and $T$. castaneum adults. Similar investigations are reporte by several authors, Kim et al., (2003) achieved a good insecticidal activity against Lasioderma serricorne adults with extracts of some parts of plants such as cinnamon (Cinnamomum cassia) bark and fennel (Foeniculum vulgare) fruit. Kim et al., (2001) demonestreated that the $F$. vulgare fruitderived materials could be useful for managing populations of three coleopteran stored-product insect. Also, Chaubey (2008) compared between seven extracted of essential oils, he found that black cumin oil (Nigella sativa) was the most potent oil against the coleopteran insect Callosobruchus chinensis by fumigation. The essential oils caused chronic toxicity as the insect fumigants, which caused less damage to the stored grains. In addition, the toxicity of essential oils to stored-product insects was influenced by the chemical composition of the oil, which in turn depends on the source, season and ecological conditions, method of extraction, time of extraction and plant part used (Don-Pedro, 1996 and Lee et al., 2001). A large number of powders and essential oils from natural products have been used as bio-pesticides against different insect pests since they present no risk to humans and the environment, unlike more conventional pesticides (Jayasekara et al., 2005). The growth-inhibiting, reproduction retarding, and repellent effects of bio-pesticides have also been explained against storage pests (Tunc et al., 2000 and Tripathi et al., 2002).

Results of the present study showed that the toxicity of all tested oils depended on the concentration and time of exposure. Based on the $\mathrm{LC}_{50}$ values after 6-days of exposure, all tested oils were effective on $S$. oryzae and $R$. dominica. But, toxicity of four tested oils except nutmeg oil and black cumin oil on T. castaneum were demonstrated in the results. Previous studies reported that adults of $T$. castaneum were more susceptible to essential 
oils or their components than those of other insect species. By Shaaya et al., (1997) evaluated the fumigant toxicity of a large number of essential oils extracted from various species and herb plants against several major stored-product insects. $T$. castaneum was found to be the most resistant, compared with $S$. oryzae, $R$. dominica and Oryzaephilus surinamensis, to most tested essential oils. Also, the essential oils were found to be toxic when applied topically or by fumigation. So, the oils may be explored as a potential natural insecticide towards $T$. castaneum because of their high repellency and insecticidal activities (Zapata and Smagghe, 2010). Other results are reporte by Al-Hadidi et al., (2014) who compared between four plant extracts against T.castaneum. They found that the cinnamon oil and nutmeg oil gave excellent results against the $T$. castaneum using the plant powder. In contrast, Padin et al., (2000) evaluated the repellence, attractance, and mortality of essential oils from several herb species cultivated in Argentina on the stored grain pests $S$. oryzae and $T$. castaneum. No repellent activity was observed with any of the essential oils tested.

Finelly, The essential oil of plants may contain hundreds of different constituents but certain components will be present in larger quantities. Among the essential oil components, the monoterpenoids have drawn the greatest attention for fumigant activity against stored-product insects (Lopez and Pascual-Villalobos., 2008).

On the other hand, the data obtained are in agreement with the (El-Nahal, 1989), who reported that the period of exposure rather than the dosage appeared to be the most important factor affecting the efficiency of the vapours of the essential oil of Indian, Acorus calamus, on the adults of several stored-product insect pests such as S. oryzae, $T$. confusum and $R$. dominica. Our results are comparable with El-Disouky (2002) who found that citronella and nutmeg oils achieved 100\% mortality against $S$. oryzae adults at concentration of $0.5 \%$ after $72 \mathrm{hrs}$ of exposure. Also, anise and eucalyptus oils achieved high mortality (over 95\%) with high doses within shorter exposure periods between (24hr and144 hr.) against adults of $T$. confusum and $S$. oryzae (Sarac and Tunc, 1995). Under laboratory conditions, El- Disouky et al., (2009) evaluated some essential oils isolated from Egyptian plants (Mentha microphylla, Artemisia judaica, Eucalyptus camaldulensis and Majorana hortensis) against $S$. oryzae and $T$. castaneum in stored wheat grains. Most of essential oils treatments showed significantly higher mortality of adults of both insects after one and two weeks compared with untreated wheat grains. Also, tulsi and wintergreen oils showed maximum percentage of mortality $92 \%$ and $86 \%$ at 48 and 72 hours after treatment, respectively. Tripathi et al., (2000) showed that a significant negative correlation between doseresponse relationship of Artemisia annua oil and survival of $T$. castaneum (i.e., increase in dose caused decrease in survival and adult emergence).

\section{2- Effect of some essential oils on the insect} haemogram.

\section{1- The different haemocyte types' counts.}

The effects of some essential oils on the different haemocyte counts in the adults of $S$. oryzae, $R$. dominica and $T$. castaneum were evaluated.

Examination of stained blood smears from treated adult's of $S$. oryzae, $R$. dominica and $T$. castaneum at different concentrations of tested essential oils after 48 hours (Gad and Alzahofi, 2009). The present results revealed that five primary types of haemocytes in $S$. oryzae and $R$. dominica haemolymph of the adult. There were Prohaemocytes (Pr), Granulocytes (Gr), Plasmatocytes (Pl), Oenocytoides (Oe) and Spherule cells (Sp). While, the haemolymph of $T$. castaneum adults contain four types of haemocytes, Prohaemocytes (Pr), Granulocytes (Gr), Plasmatocytes (Pl) and Oenocytoides (Oe). These results supported with those obtained by Giulianini et al., (2003).

The different haemocyte counts were clearly affected by the tested essential oils in S. oryzae. All tested essential oils reduced the number of (Pr, Gr and $\mathrm{Pl}$ ). The maximum decrease was observed in cinnamon oil at concentration 0.0063 and 0.0072 $\mathrm{mg} / \mathrm{cm}^{2}$ in $S$. oryzae and $R$. dominica, respectively after $48 \mathrm{hrs}$ of treatmet. The percentage of (Pr) decreased significantly to be 4.3 and $7 \%$, when compared with the control 14.2 and $15 \%$ in $S$. oryzae and $R$. dominica, respectively. Also, the percentage of $(\mathrm{Pl})$ decreased from $35 \%$ in the control of $S$. oryzae to $20.2 \%$ after treatment and decreased from $34 \%$ in the control of $R$. dominica to $25.6 \%$ after treatment. Furthermore, the percentage of (Gr) significantly decreased from $45.3 \%$ in control of $S$. oryzae and $42 \%$ in $R$. dominica, to be $25 \%$ in the treatment in $S$. oryzae and $28 \%$ in $R$. dominica. The percentage of (Oe) and (Sp) significantly increased to be 19.2 and $13.2 \%$, when compared with control 7.6 and $5 \%$, respectively in $S$. oryzae. Moreover, in $R$. dominica the percentage of (Oe) and (Sp) markedly increased to be 17 and $12 \%$, while control was 6 and $5 \%$, respectively. The same trend was observed in black cumin oil treatment followed by citronella oil, nutmeg oil and caraway oil, respectively (Figures 1 and 2).

As shown in Figure (3) treatment the adults of $T$. castaneum with the cinnamon oil at a concentration of 0.0072 and citronella oil at a concentration of $0.0322 \mathrm{mg} / \mathrm{cm}^{2}$ caused significant decrease in the number of (Pr, Gr and $\mathrm{Pl}$ ) and increased the number of (Oe) except the black cumin and nutmeg oil, which have no effects 


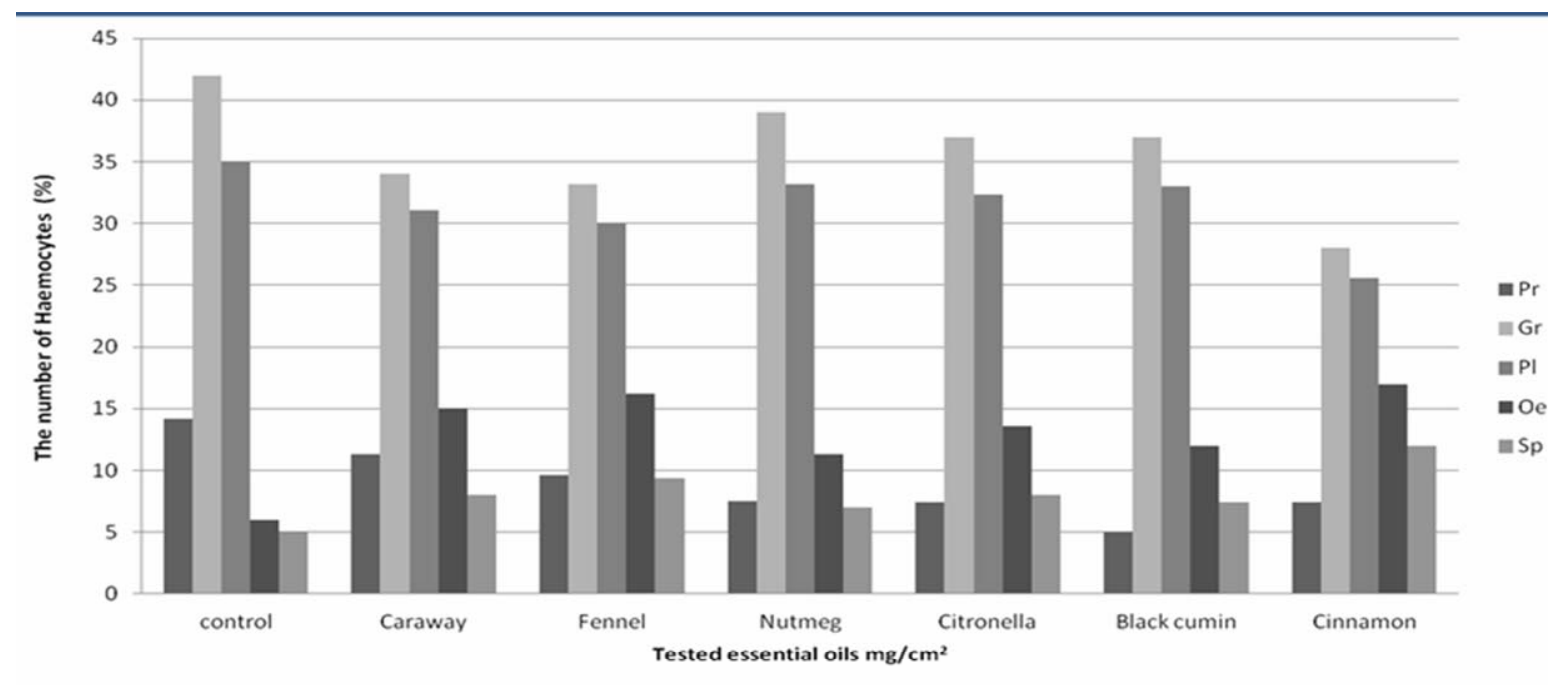

Figure 1: Effect of tested essential oils on different haemocyte types'count in S. oryzae.

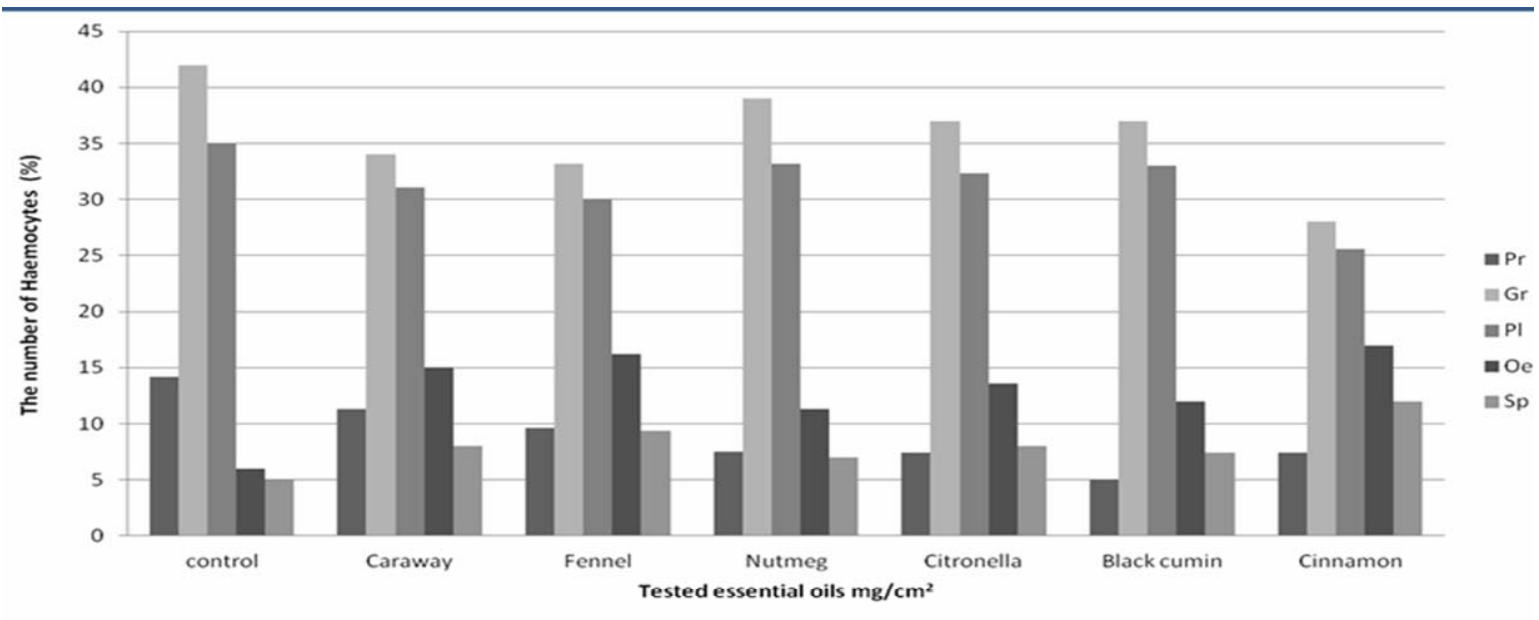

Figure 2: Effect of tested essential oils on the different haemocyte types'count in $R$. dominica.

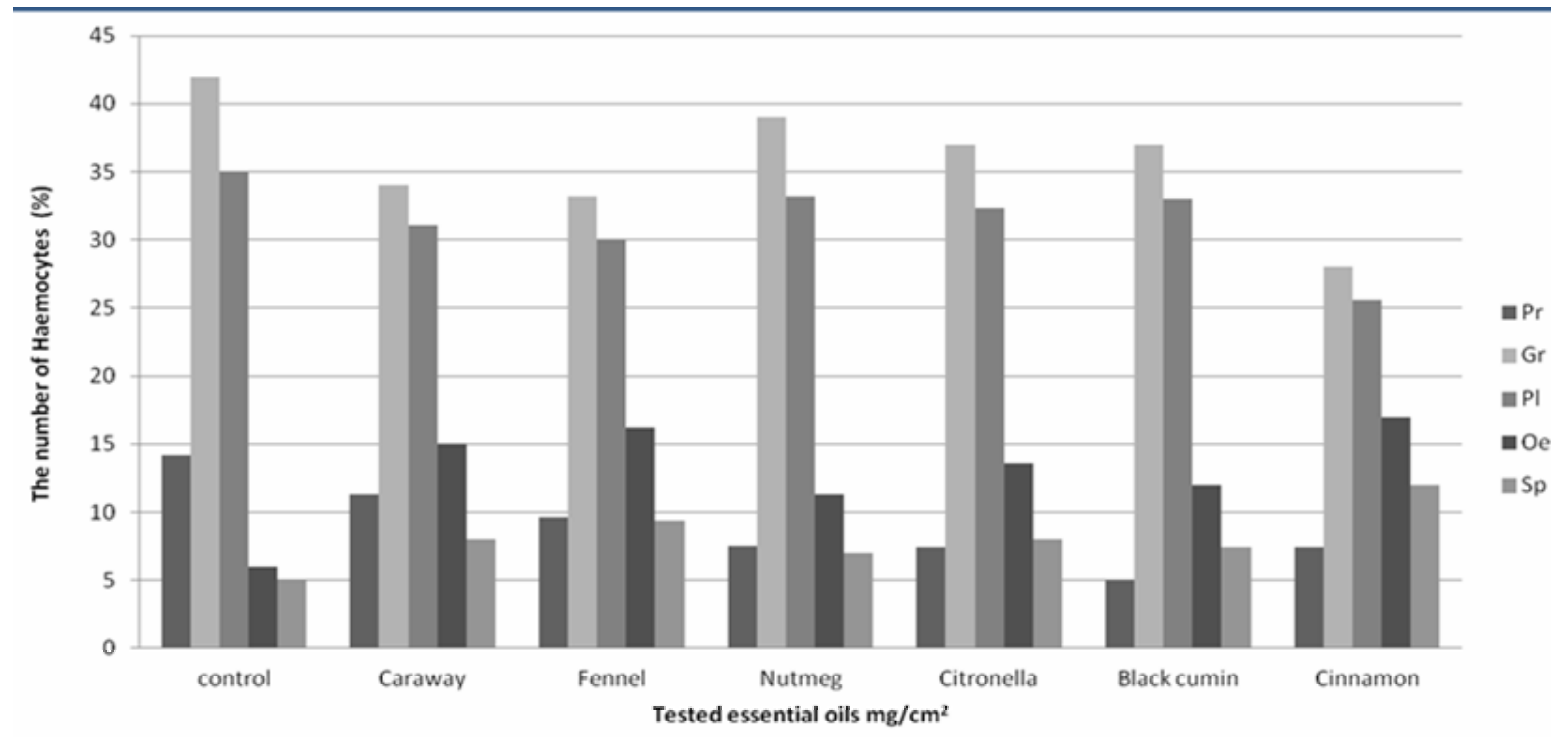

Figure 3: Effect of tested essential oils on the different haemocyte types'count in T. castaneum. 
on the adults of $T$. castaneum. Cinnamon oil significant decreased the percentage of (Pr) to be $8 \%$, while control was $12 \%$ and also, the percentage of (Gr) significantly decreased from $43 \%$ in the control to be $30 \%$ in the treatment. The same trend was observed in the percentage of $(\mathrm{Pl})$ decreased from $34 \%$ in the control to $27 \%$, while the percentage of $(\mathrm{Oe})$ significantly increased from $6 \%$ in the control to $16.3 \%$ in the treatment.

\section{2- The haemocyte surface area}

Table (11) shows the variations in the surface area of each haemocyte type in cinnamon oil treatment. The obtained results proved that all haemocytes surface areas were markedly increased when compared with the control in the haemolymph of $S$. oryzae and T. castaneum. On the other hand, treatment the adults of $R$. dominica with cinnamon oil caused slightly increase in the haemocytes surface area.

The surface area of $(\mathrm{Pr})$ was $\left(3.7 \mu \mathrm{m}^{2}\right)$ in $S$. oryzae, $\left(4.1 \mu \mathrm{m}^{2}\right)$ in $R$. dominica and $\left(5.2 \mu \mathrm{m}^{2}\right)$ in $T$. castaneum, while in the control was $\left(3.1 \mu \mathrm{m}^{2}\right)$, $\left(3.6 \mu \mathrm{m}^{2}\right)$ and $\left(4.5 \mu \mathrm{m}^{2}\right)$, respectively. The same trend observed in the surface area of (Gr) was $\left(5.5 \mu \mathrm{m}^{2}\right)$ in $S$. oryzae, $\left(8.2 \mu \mathrm{m}^{2}\right)$ in $R$. dominica and $\left(13.3 \mu \mathrm{m}^{2}\right)$ in $T$. castaneum, while in the control was $\left(5.1 \mu \mathrm{m}^{2}\right),\left(7.3 \mu \mathrm{m}^{2}\right)$ and $\left(12.6 \mu \mathrm{m}^{2}\right)$, respectively. Also, in $(\mathrm{Pl})$ was $\left(6.0 \mu \mathrm{m}^{2}\right)$ in $S$. oryzae, $\left(8.0 \mu \mathrm{m}^{2}\right)$ in $R$. dominica and $\left(12.5 \mu \mathrm{m}^{2}\right)$ in T. castaneum, while in the control was $\left(5.4 \mu \mathrm{m}^{2}\right),\left(7.3 \mu \mathrm{m}^{2}\right)$ and $\left(11.2 \mu \mathrm{m}^{2}\right)$, respectively.

The same trend observed with (Oe) in S. oryzae $\left(5.6 \mu \mathrm{m}^{2}\right)$ and $R$. dominica $\left(12.5 \mu \mathrm{m}^{2}\right)$, while in the control was $\left(5.6 \mu \mathrm{m}^{2}\right)$ and $\left(9.3 \mu \mathrm{m}^{2}\right)$, respectively. Besides, there was a significant increased in the (Oe) surface area in the haemolymph of $T$. castaneum treatment with cinnamon oil $\left(20.3 \mu \mathrm{m}^{2}\right)$ when compare with the control $\left(13.2 \mu \mathrm{m}^{2}\right)$. The surface area of $(\mathrm{Sp})$ was $\left(4.7 \mu \mathrm{m}^{2}\right)$ in $S$. oryzae and $\left(9.3 \mu \mathrm{m}^{2}\right)$ in $R$. dominica, while in the control was $\left(4.2 \mu \mathrm{m}^{2}\right)$ and $\left(8.1 \mu \mathrm{m}^{2}\right)$, respectively.
The present results in this concern were in agreement with the results of Saxena and Tikku (1990). They observed that plumbagin, a phytochemical, eliminated the prohaemocytes while granulocytes and plasmatocytes decline continuously after 24 - $48 \mathrm{hrs}$ of treatment of Dysdercus koenigii F. (Heteroptera). Also, Arnold (1974) noted a high mitotic and a rapid turnover of Oenocytoids, possibly as a mechanism of releasing products of their metabolism into the haemolymph. On the other hand, Sharma et al., (2008) studied the effect of sweet flag rhizome oil (Acorus calamus) on haemogram of Spodoptera litura. They observed that all the concentrations of oil caused the injury to both $(\mathrm{Pl})$ and $(\mathrm{Gr})$ and also affected the haemogram. While, Wael et al., (2016) reaveled that apricot kernel extract treatment, caused a reduction in the percentage of the $(\mathrm{Pr}),(\mathrm{Gr})$ and $(\mathrm{Pl})$ in $2^{\text {nd }}$ larval instar of $S$. littoralis. It is clear that, irrespect of haemocytes, all different haemocyte types' surface areas especially (Oe), in cinnamon oil always exceed those of the control. The present findings agreed with those obtained by Gad and El-DaKheel (2009) who proved that cinnamon and chamomile oils treatment has increased the haemocyte surface area than control in Culex quinquefasciatus larvae. Also, Abou-Taleb et al., (2015) reported a decrease in the different haemocyte counts and corpora allata (CA) activity in $4^{\text {th }}$ larval instar of $S$. littoralis after treatment with insecticides lufenuron and chlorfluazuron. Moreover, Saxena and Tikku (1990) demonstrated that plumbagin treatment caused damage in haemocyte and suppression of filopodial elongations of plasmatocytes and granulocytes (the types that are active in defense mechanism). While, Arnold and Hinks (1983) noticed a high mitotic and a rapid turnover of Oenocytoids, possibly as a mechanism of releasing products of their metabolism into the haemolymph. Also, Sharma et al., (2008) demonestrated that the major effect of oil treatment was observed on plasmatocytes (Pl) and granular haemocytes $(\mathrm{Gr})$.

Table 11: Effect of cinnamon oil on surface area of different haemocyte types' in tested insects.

\begin{tabular}{|c|c|c|c|c|c|c|}
\hline \multirow{2}{*}{ Insects } & \multirow{2}{*}{ Essential oils } & \multicolumn{5}{|c|}{ Haemocytes surface area $\left(\mu \mathrm{m}^{2}\right)$} \\
\hline & & $\operatorname{Pr} *$ & Gr * & PI * & Oe $*$ & $\mathrm{Sp} *$ \\
\hline S. oryzae & Control & $3.1 \pm 0.4^{\mathrm{a}}$ & $5.1 \pm 0.9^{\mathrm{a}}$ & $5.4 \pm 1.1^{\mathrm{a}}$ & $5.6 \pm 0.6^{\mathrm{a}}$ & $4.2 \pm 0.5^{\mathrm{a}}$ \\
\hline R. dominica & Control & $3.6 \pm 0.5^{\mathrm{a}}$ & $7.3 \pm 1.2^{\mathrm{a}}$ & $7.3 \pm 1.2^{\mathrm{a}}$ & $9.3 \pm 1.2^{\mathrm{a}}$ & $8.1 \pm 0.7^{\mathrm{a}}$ \\
\hline \multirow[b]{2}{*}{ T. castaneum } & Control & $4.5 \pm 0.4^{\mathrm{a}}$ & $12.6 \pm 0.7^{\mathrm{a}}$ & $11.2 \pm 1.6^{\mathrm{a}}$ & $13.2 \pm 1.6^{\mathrm{a}}$ & ------ \\
\hline & $\begin{array}{l}\text { Cinnamon } \\
\left(0.0064 \mathrm{mg} / \mathrm{cm}^{2}\right)\end{array}$ & $5.2 \pm 0.8^{\mathrm{a}}$ & $13.3 \pm 1.3^{\mathrm{a}}$ & $12.5 \pm 1.2^{\mathrm{a}}$ & $20.3 \pm 1.2^{b}$ & ------ \\
\hline
\end{tabular}

* Pr, Prohaemocytes; Gr, Granulocytes; Pl, Plasmatocytes; Oe, Oenocytoides and Sp, Spherule cells.

*Each value represents the mean $\pm \mathrm{SE}$.

* Mean in same column followed by the same letters are not significant.

Probability level at 0.05 . 
In the conclusion, the investigated plant essential oils can play an important role in control of stored-grain insects and reduce the need for the use of insecticides. It could be recommended for use as a part of integrated pest management program of $S$. oryzae, $R$. dominica and $T$. castaneum in storedgrains.

\section{REFERENCES}

Abbott, WS.A. 1925. Method of computing the effectiveness of insecticide. J.Econ.Ent. 18: 265-267.

Abou-Taleb, H. K., H. M. Zahran and A. A. Gad. 2015. Biochemical and physiological effects of lufenuron and chlorfluazuron on Spodoptera littoralis (Boisd.) (Lepidoptera: Noctuidae). J. Econ. Entomol. 12(2): 77-86.

Al- Hadidi, S.N., N.A. Khamas and H.A. Mtunai. 2014. Effect of using some spices to control the adults of red flour beetle Tribolium castaneum (Herbest) (Coleoptera: Tenebrioidae). J. Diyala. Sci., Diyala Univ. 6 (2): 248- 257.

Arnold, J. W. 1974. The hemocytes of insects. In: Rockstein, M. (ed.). The Physiology of Insecta. New York, Academic Press. 5: 201255.

Arnold,J.W. and H. Hinks.1983. Haemoposiesis in Lepidoptera. The multiplication of circulation haemocytes. Can.J.Zoo. 154: 1003-1012.

Basilico, M.Z. and J.C. Basilico. 1999. Inhibitory effects of some spice essential oils on Aspergillus ochraceus NRRL 3174 growth and ochratoxin A production. Lett. Appl.Microbiol. 29: 238-241.

Bruneton, J. 1999. Pharmacognosy, Phytochemistry, Medicinal Plants: Essential oils. $2^{\text {nd }}$ ed. Lavoisier Publishing, New York. 461-780.

Chaubey. 2008. Fumigant toxicity of essential oils from some common species against pulse Beetle, Callosobruchus chinensis (Coleoptera:Bruchidae). J. Oleo Sci. 57(3): 171-179.

Don-Pedro, K.N. 1996. Fumigant toxicity is the major route of insecticidal activity of citrus peel essential oils. Pestic. Sci. 46: 71-78.

El-Disouky, M.S. 2002. Efficacy of insecticide formulations and alternative methods against certain insects. Ph. D. Thesis in Chemistry of Pesticide, Fac. of Agric. Alex. Univ. Egypt.

EL-Disouky, M.S., A. M. Smir and A. A.Mona. 2009. Potential of Essential Oils to Control Sitophilus oryzae (L.) and Tribolium castaneum (Herbst) on Stored Wheat. Alex. Sci. Exch. Jour. 30(4): 419-426.
El-Nahal, A.K.M., G.H. Schmidt and E.M. Risha. 1989. Vapours of Acorus calamus oil-a space treatment for stored-product insects. J. Stroed Prod. Res. 25(4): 211-216.

Gad, Abir A. 2006. Haemocytes of some Homopterous insects. Alexandria Journal of Agriculture Research, 50(3): 67-74.

Gad, Abir A. and Nora N. Alzahofi. 2009. Changes in the haemocytes of Bombyx mori larvae (Lepidoptera: Bombycidae) in relation to Bacillus thuringensis infection. The Egypt. Sci. Magaz. 6 (1/2): 15 - 22.

Gad, Abir A. and Abeer A. El-DaKheel. 2009. Larvicidal activities of Cinnamomum osmophloeum and Matricharia chamomella extracts against the filarial mosquito Culex quinquefasciatus (Diptera:Culicidae) and their effects on its haemogram. Egypyt. Sci. Mag. 6 (1): 8 - 14.

Gbolade, A.A., A.O. Oyedele, M.B. Sosan, F.B. Adewayin and O.L. Soyela. 2000. Mosquito repellent activites of essential oils from two Nigerian Ocimum species. J. Trop. Med. Plants. 1: 146-148.

Giulianini. P.G., F. Bertolo., S. Battistella and G.A. Amirante. 2003. Ultrastructure of the hemocytes of Cetonischema aeruginosa larvae (Coleoptera, Scarabaeidae): involvement of both granulocytes and oenocytoids in in vivo phagocytosis. Tissue Cell. 35(4): 243-251.

Isman, M.B. 2006. Botanical insecticides, deterrents, and repllents in modern agriculture and an increasingly regulated world. Ann. Rev. Entomol. 51: 45-66.

Isman, M.B. 2008. Perspective botanical insecticides: for richer, for poorer. Pest Manag. Sci. 64: 8-11.

Jayasekara, T.K., P.C. Stevenson, D.R. Hall and S.R. Belmain, J. 2005. Effect of volatile constituents from Securidaca longepedunculata on insect pest's on stored grain. J Chem. Ecol. 31(2): 303- 313.

Kim, D., A. Y. Joon, K. Dh and A. YJ. 2001. Contact and fumigant activites of constituents of Foeniculum vulgare fruit against three coleopteran stored-product insect. PestManagement-Sci. 57(3): 301-306.

Kim, S.I., C. Park, M.H. Ohh, H.C. Cho and Y.J. Ahn. 2003. Contact and fumigant activities of aromatic plants extracts and essential oil against Lasioderma serricorne (coleoptera: Anobiidae). J. Stored Prod. Res. 39: 9-11.

Kubo, I., H. Muroi and A. Kubo. 1994. Naturally occurring antiacne agents. J. Nat. Prod. 57: 917. 
Lee, B., C. Wonsik, L. Sungeun, P. Byeoungsoo, L. Bh, C. Ws, L. Se and P. Bs. 2001. Fumigant toxicity of essential oils and their constituent compounds towards the rice weevil, Sitophilus oryzae (L.). Cropprotection. 20(4): 317-320.

Lopez, M.D. and M.J. Pascual-Villalobos. 2008. Mode of a cetylcholin estrase by Monoterpenoids and implications for pest control. Ind. Crop prod. 31: 284-288.

Martha, G. and S. Hachiro. 1971. Blood cells of the worker honey bee. J. Apic. Res.10(2):79-85.

Padin, S., R. Ja., D. Bello, C. El, R. Ms and H. Cp. 2000. Toxicology and repellent activity of essential oil on Sitophilus oryzae L. and Tribolium Castaneum Herbest. J. of Herbs, spices and medicinal- plant. 7(4): 67-73.

Pugazhvendan, S.R., K. Elumalai, P. Ronald Ross and M. Soundarajan. 2009. Repellent activity of choosen plant species against Tribolium castaneum. Wolrd Zool. 4(3): 188-190.

Qi, Y.T. and W. Burkholder. 1981. Protection of stored wheat from the granary weevil by vegetable oils. J. Econ. Entomol. 74: 502-505.

Rajendran S. and V. Srianjini. 2008. Plant products as fumigants for stored product insects control. J. Stored Prod. Res. 44: 126-135.

Sarac, A. and I. Tunc. 1995. Toxicity of essential oil vapours to stored- product insects. Zeitscift-fur-Pflanzenkrankheiten - undPflanzenschutz. 102(1): 69-74.

Saxena, B.P. and K. Tikku. 1990. Effect of plumbagin on haemocytes of Dysdercus koenigii F. J. Animal Sciences. 99(2): 119124.

Shaaya, E., M., Kostjukovsk, J. Eilberg and C. Sukprakarn. 1997. Plant oils as fumigants and contact insecticides for the control of stored product insects. J. Stored Prod. Res. 33(1): 715.
Sharma, P.R., O.P. Sharma and B.P. Saxena. 2008. Effect of sweet flag rhizome oil (Acorus calamus) on hemogram and ultrastructure of hemocytes of the tobacco armyworm, Spodoptera litura (Lepidoptera: Noctuidae). J. Micron. 39(5): 544-551.

Steel, R.G. and J. H.,Torrie. 1980. Principles avd procedures of statistics Abiometrical approach, $2^{\text {nd }}$ Mc. Graw- Hill Book Co., New York.

Tripathi, A., V. Prajapati, A.K.K. Sps, S. Kumal, V. Prajapati and S. Kumar. 2000. Repellency and toxicity of oil from Artemisia annua to certain stored product beetles. J. Econ. Entomol., 93(1): 43-47.

Tripathi, A.K., V. Prajapati, N. Verma, J.R. Bahl, R.P. Bansal, S.P Khanuja and S. Kumar. 2002. Bioactivities of the leaf essential oil of Curcuma longa(var. ch-66) on three species of stored-product beetles (Coleoptera). J. Econ. Entom. 95(1): 183-189,

Tunc, L.B., M. Berger, F. Erler and F. Dagli. 2000. Ovicidal activity of essential oils from five plants against two stored product insects. J. Stored. Prod. Res. 36: 161-168.

Wael M. Khamis ; Sahar E. El-Desouky and Abir A. Gad. 2016. Toxicity and antifeedant effects of Apricot Kernel extract and its main components against cotton leaf worm, Spodoptera littoralis (Lepidoptera: Noctuidae) larvae with reference to Some physiological effects. Alex.Sci.Exch. J. 37 (4): 637-646.

Zapata N. and G. Smagghe. 2010. Repellency and toxicity of essential oils from the leaves and bark of laurelia semper virens and Drimys winteri against Tribolium castaneum. 1nd.Crop.Prod. 32: 405-410. 


\section{الماخص المري}

\section{ققيمستة زبوت نبلتية ضد نالث ألنواع من مشرات المواد المخزونة وتلثيرلتها عل صورة الم تهت الاروف المعملية}

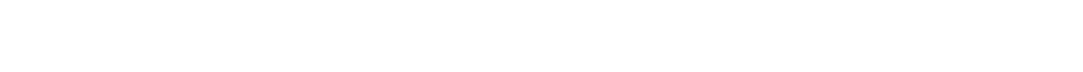

قسم علم الهررات والحيوان الطبيق، كلية الزراعة - جلمعة الأسكندرية المعيد

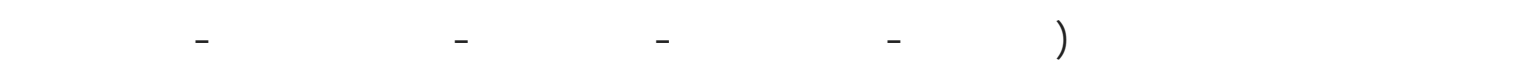

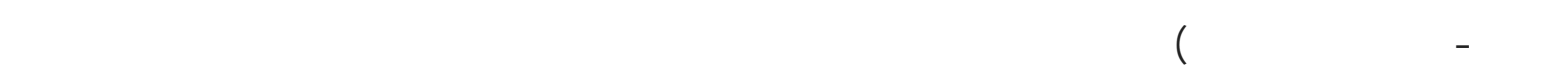

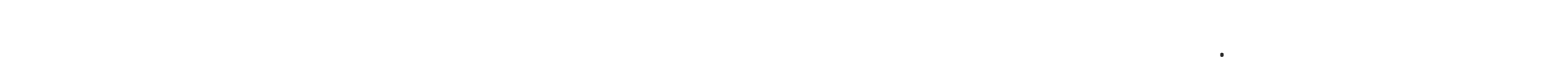
أدت إلى زياة كبيرة في نسبة الموت للمثرات المثات المعلملة.

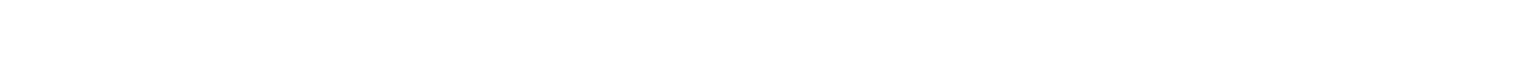

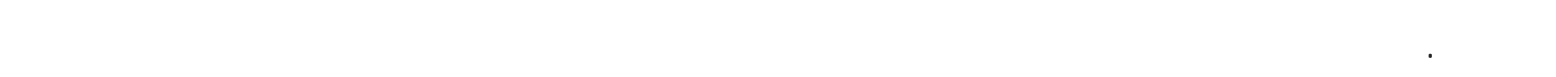
بزياة التركيز المستخم للازيت.

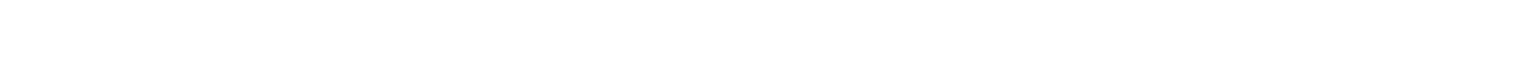

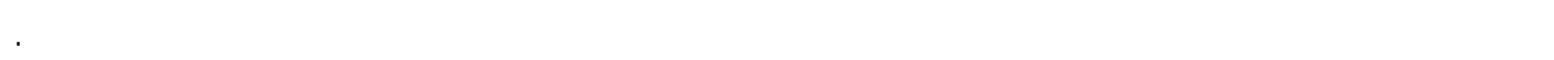

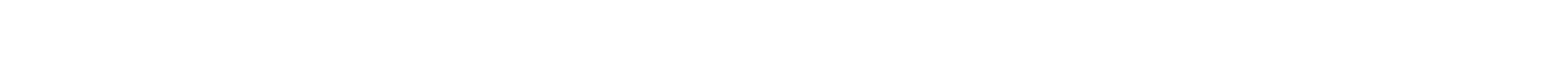

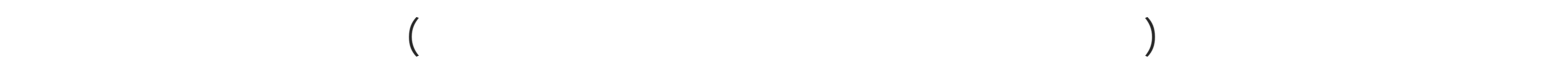
حول كفية الطبيق فى المخازن والصوامع. 